\title{
Transparency report delay and disclosure by Croatian audit firms
}

\author{
Marko Čular ${ }^{1, \dagger}$ \\ ${ }^{1}$ Faculty of Economics, University of Split, Cvite Fiskovića 5, 21000 Split, Croatia \\ E-mail: 〈mcular@efst.hr〉
}

\begin{abstract}
The aim of this paper is to investigate transparency report (TR) disclosure and determinants of TR delay, using Croatian listed companies and audit firms who audited Croatian listed companies in 2015. TR disclosure is measured using the TR index whereas the TR delay is measured as the number of days between the financial year-end and the publication date of the TR by an audit firms. We first analyzed the position and difference between audit firm indicators and types of audit firm using the following: number of certified auditors, number of employees, average net salary, total revenue, net profit, net working capital, total assets, total capital and financial ratio. Second, we used the TR index to determine the existence of TR elements and whether the audit firm made a disclosure. Finally, we used multiple regressions for modelling the TR delay as a function of the following variables: number of certified auditors, number of audits per year, return on assets and the TR index. Our results indicate that based on the TR index only $32 \%$ audit firms are transparent. Furthermore, the TR delay is shorter when audit firms have a greater number of certified auditors and a higher TR index, i.e. when audit firms incorporate more elements into the TR.
\end{abstract}

Keywords: transparency report, Croatian audit firms, disclosure, delay

Received: January 7, 2017; accepted: March 30, 2017; available online: March 31, 2017

DOI: $10.17535 /$ crorr. 2017.0019

\section{Introduction}

Transparency reporting can foster internal introspection and discipline within audit firms and may encourage audit firms to sharpen their focus on audit quality, which would also be of benefit to investors and other stakeholders. In addition, in comparing audit firms competing for an audit engagement, an audit firm's transparency reporting can aid those responsible when deciding on an auditor for a public company by providing information on the auditing quality of a firm [8]. Regulators and standard-setters argue that greater transparency of the internal governance of audit firms reduces information asymmetry between audit firms

$\dagger$ Corresponding author 
and market participants, thus maintaining high-quality audit services and stability of capital markets [5].

Quality assurance is the main tool of the audit profession. Its purpose is to convince the public that auditors or audit firms operate at a level that meets established auditing standards and ethical rules [10]. It is not only a tool for disciplinary sanctions, but also aims to enforce, demonstrate and improve audit quality. The transparency of audit firms has a significant role in achieving a higher level of quality in audit practices. An important characteristic of good quality information provided to external users is full disclosure and transparency. Transparency of information means creating an environment where information is accessible and understandable for all market participants [11]. IOSCO believes that if transparency reports are published by audit firms, they should then be made available at least on an annual basis and timely provided after an audit firm's fiscal year-end to be useful to investors. These reports should be published in a manner that is visible and easily accessible to investors, regulators and other stakeholders [8].

Therefore, this study expands on previous literature on transparency reporting and analyzes potential determinants of delays in transparency report in Croatia. The reminder of this paper is structured as follows. The next section provides a background in transparency reporting. The third section describes empirical findings. Finally, the last section summarizes the main findings of the research.

\section{Transparency report background}

\subsection{Transparency report of audit firms}

The transparency report, also called an Audit Quality Report, is a public report published by an audit firm providing information about the firm's organizational structure, governance and systems for ensuring audit quality [1]. The International Auditing and Assurance Standards Board's (IAASB) recognizes the role that transparency reporting plays in enhancing audit quality. The IAASB believes it should promote an understanding of the demand and requirements for transparency reporting around the world and how investors and other are using these reports [9]. The purpose of transparency reporting is to foster greater confidence in the audit process by assisting stakeholders in understanding how an audit firm's management and operations support the performance of high quality audit [1].

The UK's Financial Reporting Council (FRC) and the International Organization of Securities Commission (IOSCO) has pursued to address these issues is to consider the role of audit firms, and in particular the practices employed by audit firms to be transparent in their own reporting to investors and other stakeholders about the firm itself, notably, with respect to firm governance and elements of their system of quality control for their financial statement audits. IOSCO 
recognizes that transparency reporting by audit firms is a fairly recent practice that is evolving, as it evident by its work in this area and this Statement [8].

IOSCO believes that an transparency reporting by audit firms should provide information that is [8]: (a) clear, useful and presented in sufficient detail to be meaningful to different users of the report; (b) fact-based and not potentially misleading; (c) unbiased and not oriented toward marketing or selling services; (d) concise, specific to the firm and avoiding the use of boilerplate language; (e) timely, accurate and complete; (f) balanced in communicating the output measures of an audit firm for audit quality in addition to any input measures; $(\mathrm{g}$ ) sufficient in terms of explaining the limitations of audit quality indicators.

In many jurisdictions, audit firms are required to publish transparency reports. In the European Union (EU), Australia and in Japan there are mandatory requirements for publishing transparency reports. In the EU, the first mandatory transparency report for public companies was in 2008. Also, the first transparency report for all audit firms in Australia was mandatory in 2013. Finally, the first mandatory transparency report for all audit firms in Japan was in 2008. In Canada and USA there are no mandatory requirements for publishing transparency reports, but the $\mathrm{CPAB}$ oversees Canadian auditors and requires each participating audit firms to prepare non-public quality control reports. Also, the US Treasury Advisory Committee recommended increased transparency in the governance of audit firms. Specifically, the Committee suggested that audit firms with 100 or more public clients should produce transparency reports annually [7].

In 2014, European Union (EU) requirements for transparency reporting by audit firms complied with Regulation No. 537/2014 on specific requirements regarding statutory audit of public-interest entities (European Parliament and Council, 2014, article 13). In accordance with this Article, a statutory auditor or an audit firm that carries out statutory audits of public-interest entities shall make public an annual transparency report with four months after the end of each financial year. The transparency report shall be published on the website of the statutory auditor or the audit firm and remain available on the website for at least five years from the day of its publication on the website. Statutory auditors and audit firms shall communicate to the competent authorities that the transparency report has been published on the website of the statutory auditor or the audit firm or, as appropriate, that it has been updated. All main transparency report elements in Croatia comply with this Regulation and are presented in next Chapter. These elements are similar for all jurisdictions where mandatory requirements for publishing transparency report exist. 


\subsection{Review of transparency report literature}

Reviews of available literature, similar topics regarding the transparency of audit firms have rarely been investigated. Pott, Mock and Watrin [13] investigated the effect of transparency reporting on auditor independence and the results indicate that there is no significant perceived difference as to whether the transparency report is mandatory or voluntary, or whether the report is audited or not. Ehlinger [6] researched determinants in transparency reporting for Austrian, German and Netherland audit firms and concluded as follows: there is a difference between observed countries in terms of given information quantity; there is a difference between annual periods in quality of provided information; there is a positive correlation between company size and extent of information; there is a difference between the Big Four and other audit firms on releasing information; there is a difference between audit firm size and auditor independence; there is a difference between companies that are members of the network and those that are not members.

Pivac and Čular [11] analyze audit firms that audited Croatian listed companies in order to establish a quality index of transparency reporting. The conclusions are as follows: $1 / 3$ companies are audited by the Big Four; $5 \%$ of Croatian listed companies have no information about their auditors; 57 audit firms audited Croatian listed companies (research sample); $2 / 5$ of the transparency reports are not available; $1 / 5$ of audit firms are transparent. The audit firms, in terms of releasing the essential elements of transparency reports, are not in compliance with legal legislations. Deumes, Schelleman, Van der Bauwhede and Vanstraelen [5] identified variations in the extent and type of governance disclosure across 103 audit firms in four EU countries based on a self-constructed disclosure index. However, they find no association between the variations in the disclosure score and proxies of audit quality. Finally, Fu, Carson and Simnett [7] found that Australian audit firms do meet the minimum transparency report disclosure requirements, but have different approaches to governance in areas that may impact audit quality. These areas include: the internal quality control systems, independence practices, continuing education and partner remuneration structures.

\section{Empirical findings}

\subsection{Sample description and descriptive analysis}

This research was conducted on a sample of Croatian listed companies and on audit firms who audited Croatian listed companies in 2015. First, we took from the Zagreb Stock Exchange (ZSE) website the names of all companies listed on 
the official and regular market (total of 144 listed companies). The Register of Financial Statements created by the Financial Agency (FINA) is used to search for names of audit firms that audited Croatian listed companies (we did not find information who audited 7 listed companies, hence we used a sample of 137 listed companies).

To get the results on transparency reports, we targeted 37 audit firms that audited 137 Croatian listed companies on the official and regular market. These audit firms are obligated under the Croatian Audit Act to publish transparency reports (no transparency reports found for 2 audit firms, hence we used a final sample of 35 audit firms). After that, we used and read 35 transparency reports of the respective audit firms (from the websites of the audit firms or from the official Croatian Audit Chamber website) to establish the transparency report index (i.e., to identify elements of a transparency report). In all, $23 \%$ of audit firms published their transparency reports on the official website of the Croatian Audit Chamber and $37 \%$ of audit firms belong to an audit firm network. Other information necessary for the analysis (number of certified auditors, number of employees, average net salary, total revenue, net profit, net working capital, total assets, total capital and financial ratio) was sourced from the business website Poslovna.hr.

Table 1 and 2 provide a descriptive analysis of indicators relating to audit firms. Next, we used the Mann-Whitney U test to find the difference between all these indicators and the type of audit firms. The computer program used was the IBM SPSS 22 (Statistical Package for the Social Sciences).

Number of audits: In all, $45 \%$ of Croatian listed companies were audited by the Big Four audit firms. Using the Mann-Whitney U test, the difference between the number of audits and type of audit firm was defined (Table 1, Part 1). As is evident, a higher mean rank of the number of audits is attributed to the Big Four audit firms (mean rank equivalent to 31.38). Also, based on a significance of $0.2 \%$, we can conclude that there is a significant difference between the number of audits and the type of audit firm.

Number of certified auditors: The average number of certified auditors is 6 (total number of certified auditors in our sample is 201), hence the average number of certified auditors in the Big Four audit firms is 16 (total number of certified auditors in our sample of the Big Four is 62). Using the Mann-Whitney $\mathrm{U}$ test, the difference between the number of certified auditors and the type of audit firm was identified (Table 1, Part 2). As is evident, the Big Four audit firms have a higher mean rank for the number of certified auditors (mean rank equivalent to 31.75). Also, based on a significance of $0.3 \%$, we can conclude that there is a significant difference between the number of certified auditors and type of audit firm.

Number of employees: The average number of employees is 18 (total number of employees in our sample is 622), hence the average number of employees in the Big Four audit firms is 97 (total number of employees of the Big Four in our 
sample is 387). Using the Mann-Whitney $U$ test, the difference between number of employees and type of audit firm was defined (Table 1, Part 3). As is evident, the mean rank of the number of the employees in Big Four audit firms is higher (mean rank equivalent to 33.50). Also, based on a significance of $0.1 \%$, we conclude that there is a significant difference between the number of employees and the type of audit firm.

Net salary: The average net salary in the audit firms is HRK 6.871, while the average net salary in the Big Four audit firms is HRK 9.980. Using the MannWhitney $U$ test, the difference between the net salary and the type of audit firm was identified (Table 1, Part 4). As is evident, mean rank of the net salary in the Big Four audit firms is higher (mean rank equivalent to 31.50). Also, based on a significance of $0.3 \%$, we can conclude that there is a significant difference between the net salary and the type of audit firm.

Total revenue: The average total revenue in audit firms is HRK 9.764.237, while the average total revenue in the Big Four audit firms is HRK 55.198.050. Using the Mann-Whitney U test, the difference between the total revenue and the type of audit firm was defined (Table 1, Part 5). As can be seen, the mean rank of total revenue in the Big Four audit firms is higher (mean rank equivalent to 33.25). Also, based on a significance of approximately $0 \%$, we can conclude that there is a significant difference between total revenue and the type of audit firm.

\begin{tabular}{|c|c|c|c|c|c|}
\hline \multicolumn{3}{|c|}{-1-Number of audits } & \multicolumn{3}{|c|}{-2-Number of certified auditors } \\
\hline \multicolumn{3}{|c|}{ Descriptive statistics } & \multicolumn{3}{|c|}{ Descriptive statistics } \\
\hline $\begin{array}{l}\text { Audit firm } \\
\text { type }\end{array}$ & $\mathrm{n}$ & $\%$ & $\begin{array}{l}\text { Audit firm } \\
\text { type }\end{array}$ & \multicolumn{2}{|c|}{ Mean } \\
\hline Big 4 & 61 & 45 & Big 4 & \multicolumn{2}{|c|}{16} \\
\hline Non Big 4 & 76 & 55 & Non Big 4 & \multicolumn{2}{|c|}{ 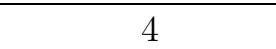 } \\
\hline Total & 137 & 100 & Mean & \multicolumn{2}{|c|}{6} \\
\hline \multicolumn{3}{|c|}{ Mann Whitney U test } & \multicolumn{3}{|c|}{ Mann Whitney U test } \\
\hline $\begin{array}{l}\text { Audit firm } \\
\text { type }\end{array}$ & $\begin{array}{l}\text { Mean } \\
\text { Rank }\end{array}$ & $\begin{array}{l}\text { M-W } \\
\text { (sig.) }\end{array}$ & $\begin{array}{l}\text { Audit firm } \\
\text { type }\end{array}$ & $\begin{array}{l}\text { Mean } \\
\text { Rank }\end{array}$ & $\begin{array}{l}\text { M-W } \\
\text { (sig.) }\end{array}$ \\
\hline Big 4 & 31.38 & \multirow{2}{*}{0.002} & $\operatorname{Big} 4$ & 31.75 & \multirow{2}{*}{0.003} \\
\hline Non Big 4 & 16.27 & & Non Big 4 & 16.23 & \\
\hline \multicolumn{3}{|c|}{-3-Number of employees } & \multicolumn{3}{|c|}{-4-Net salary } \\
\hline \multicolumn{3}{|c|}{ Descriptive statistics } & \multicolumn{3}{|c|}{ Descriptive statistics } \\
\hline $\begin{array}{l}\text { Audit firm } \\
\text { type }\end{array}$ & \multicolumn{2}{|c|}{ Mean } & $\begin{array}{l}\text { Audit firm } \\
\text { type }\end{array}$ & \multicolumn{2}{|c|}{ Mean } \\
\hline Big 4 & \multicolumn{2}{|c|}{97} & Big 4 & \multicolumn{2}{|c|}{$\begin{array}{c}\text { HRK } \\
9,980.00\end{array}$} \\
\hline
\end{tabular}




\begin{tabular}{|c|c|c|c|c|c|}
\hline Non Big 4 & \multicolumn{2}{|c|}{8} & Non Big 4 & \multicolumn{2}{|c|}{$\begin{array}{c}\text { HRK } \\
6,457.00\end{array}$} \\
\hline Mean & \multicolumn{2}{|c|}{18} & Mean & \multicolumn{2}{|c|}{$\begin{array}{c}\text { HRK } \\
6,871.00 \\
\end{array}$} \\
\hline \multicolumn{3}{|c|}{ Mann Whitney U test } & \multicolumn{3}{|c|}{ Mann Whitney U test } \\
\hline $\begin{array}{l}\text { Audit firm } \\
\text { type }\end{array}$ & $\begin{array}{l}\text { Mean } \\
\text { Rank }\end{array}$ & $\begin{array}{l}\text { M-W } \\
\text { (sig.) }\end{array}$ & $\begin{array}{l}\text { Audit firm } \\
\text { type }\end{array}$ & $\begin{array}{l}\text { Mean } \\
\text { Rank }\end{array}$ & $\begin{array}{l}\text { M-W } \\
\text { (sig.) }\end{array}$ \\
\hline Big 4 & 33.50 & \multirow{2}{*}{0.001} & Big 4 & 31.50 & \multirow{2}{*}{0.003} \\
\hline Non Big 4 & 16.00 & & Non Big 4 & 15.63 & \\
\hline \multicolumn{3}{|c|}{-5-Total revenue } & \multicolumn{3}{|c|}{-6-Net profit } \\
\hline \multicolumn{3}{|c|}{ Descriptive statistics } & \multicolumn{3}{|c|}{ Descriptive statistics } \\
\hline $\begin{array}{l}\text { Audit firm } \\
\text { type }\end{array}$ & \multicolumn{2}{|c|}{ Mean } & $\begin{array}{l}\text { Audit firm } \\
\text { type }\end{array}$ & \multicolumn{2}{|c|}{ Mean } \\
\hline $\operatorname{Big} 4$ & \multicolumn{2}{|c|}{$\begin{array}{c}\text { HRK } \\
55,198,050.00\end{array}$} & Big 4 & \multicolumn{2}{|c|}{$\begin{array}{c}\text { HRK } \\
7,728,025.00\end{array}$} \\
\hline Non Big 4 & \multicolumn{2}{|c|}{$\begin{array}{c}\text { HRK } \\
3,901,809.00\end{array}$} & Non Big 4 & \multicolumn{2}{|c|}{$\begin{array}{c}\text { HRK } \\
1,358,651.00\end{array}$} \\
\hline Mean & \multicolumn{2}{|c|}{$\begin{array}{c}\text { HRK } \\
9,764,237.00\end{array}$} & Mean & \multicolumn{2}{|c|}{$\begin{array}{c}\text { HRK } \\
2,086,580.00\end{array}$} \\
\hline \multicolumn{3}{|c|}{ Mann Whitney U test } & \multicolumn{3}{|c|}{ Mann Whitney U test } \\
\hline $\begin{array}{l}\text { Audit firm } \\
\text { type }\end{array}$ & $\begin{array}{l}\text { Mean } \\
\text { Rank }\end{array}$ & $\begin{array}{l}\text { M-W } \\
\text { (sig.) }\end{array}$ & $\begin{array}{l}\text { Audit firm } \\
\text { type }\end{array}$ & $\begin{array}{l}\text { Mean } \\
\text { Rank }\end{array}$ & $\begin{array}{l}\text { M-W } \\
\text { (sig.) }\end{array}$ \\
\hline Big 4 & 33.25 & \multirow{2}{*}{0.000} & Big 4 & 31.50 & \multirow{2}{*}{0.002} \\
\hline Non Big 4 & 16.03 & & Non Big 4 & 16.26 & \\
\hline
\end{tabular}

Table 1: Descriptive statistics and the Mann Whitney U test (1)

Net profit: The average net profit in audit firms is HRK 2.086.580, while the average net profit in the Big Four audit firms is HRK 7.728.025. Using the MannWhitney $U$ test, the difference between net profit and the type of audit firm was identified (Table 1, Part 6). As can be seen, the mean rank of the net profit in the Big Four audit firms is higher (mean rank equivalent to 31.50). Also, based on a significance of $0.2 \%$, we can conclude that there is a significant difference between net profit and the type of audit firm.

Using the net profit and total revenue, we calculated the net profit margin of audit firms (NPM). The average NPM for all audit firms is $21 \%$, while the average NPM for the Big Four audit firms is $14 \%$, whereas the non Big Four audit firms have the highest value of NPM on average (value equivalent to $35 \%$ ).

Net working capital: The average net working capital of audit firms is HRK 5.863.236, while the average net working capital of the Big Four audit firms is HRK 30.264.410. Using the Mann-Whitney U test, the difference between net working capital and the type of audit firm was defined (Table 2, Part 1). As can 
be seen, the mean rank of net working capital in the Big Four audit firms was that higher (mean rank equivalent to 33.00). Also, based on a significance of approximately $0 \%$, we can conclude that there is a significant difference between net working capital and the type of audit firm.

Total assets: The average total assets of the audit firms is HRK 6.301.748, while the average total assets of the Big Four audit firms is HRK 25.524.425. Using the Mann-Whitney U test, the difference between total assets and the type of audit firm was identified (Table 2, Part 2). As can be seen, the higher mean rank of the total assets in the Big Four audit firms was higher (mean rank equivalent to 32.00 ). Also, based on a significance of $0.1 \%$, we can conclude that there is a significant difference between total assets and the type of audit firm.

\begin{tabular}{|c|c|c|c|c|c|}
\hline \multirow{2}{*}{\multicolumn{3}{|c|}{$\frac{\text {-1-Net working capital }}{\text { Descriptive statistics }}$}} & \multicolumn{3}{|c|}{-2-Total assets } \\
\hline & & & & riptive s & stics \\
\hline $\begin{array}{l}\text { Audit firm } \\
\text { type }\end{array}$ & \multicolumn{2}{|c|}{ Mean } & $\begin{array}{l}\text { Audit firm } \\
\text { type }\end{array}$ & \multicolumn{2}{|c|}{ Mean } \\
\hline Big 4 & \multicolumn{2}{|c|}{$\begin{array}{c}\text { HRK } \\
30,264,410.00\end{array}$} & $\operatorname{Big} 4$ & HRK & $25,524,425.00$ \\
\hline Non Big 4 & \multicolumn{2}{|c|}{$\begin{array}{c}\text { HRK } \\
2,714,697.00\end{array}$} & Non Big 4 & \multicolumn{2}{|c|}{$\begin{array}{c}\text { HRK } \\
3,821,403.00\end{array}$} \\
\hline Mean & \multicolumn{2}{|c|}{$\begin{array}{c}\text { HRK } \\
5,863,236.00\end{array}$} & Mean & \multicolumn{2}{|c|}{$\begin{array}{c}\text { HRK } \\
6,301,748.00\end{array}$} \\
\hline \multicolumn{3}{|c|}{ Mann Whitney U test } & \multicolumn{3}{|c|}{ Mann Whitney U test } \\
\hline $\begin{array}{l}\text { Audit firm } \\
\text { type }\end{array}$ & $\begin{array}{l}\text { Mean } \\
\text { Rank }\end{array}$ & $\begin{array}{l}\text { M-W } \\
\text { (sig.) }\end{array}$ & $\begin{array}{l}\text { Audit firm } \\
\text { type }\end{array}$ & $\begin{array}{l}\text { Mean } \\
\text { Rank }\end{array}$ & M-W (sig.) \\
\hline Big 4 & 33.00 & \multirow{2}{*}{0.000} & Big 4 & 32.00 & \multirow{2}{*}{0.001} \\
\hline Non Big 4 & 16.06 & & Non Big 4 & 16.19 & \\
\hline \multicolumn{3}{|c|}{-3-Total capital } & \multicolumn{3}{|c|}{-4-Financial ratio } \\
\hline \multicolumn{3}{|c|}{ Descriptive statistics } & Rating & $\mathrm{n}$ & $\%$ \\
\hline $\begin{array}{l}\text { Audit firm } \\
\text { type }\end{array}$ & \multicolumn{2}{|c|}{ Mean } & A & 22 & 62.90 \\
\hline Big 4 & \multicolumn{2}{|c|}{$\begin{array}{c}\text { HRK } \\
11,581,500.00\end{array}$} & B & 8 & 22.90 \\
\hline Non Big 4 & \multicolumn{2}{|c|}{$\begin{array}{c}\text { HRK } \\
2,156,112.00\end{array}$} & $\mathrm{C}$ & 3 & 8.60 \\
\hline Mean & \multicolumn{2}{|c|}{$\begin{array}{c}\text { HRK } \\
3,233,300.00\end{array}$} & $\mathrm{D}$ & 1 & 2.90 \\
\hline \multicolumn{3}{|c|}{ Mann Whitney U test } & $\mathrm{E}$ & 1 & 2.90 \\
\hline $\begin{array}{l}\text { Audit firm } \\
\text { type }\end{array}$ & $\begin{array}{l}\text { Mean } \\
\text { Rank }\end{array}$ & $\begin{array}{l}\text { M-W } \\
\text { (sig.) }\end{array}$ & Total & 35 & 100.00 \\
\hline
\end{tabular}




\begin{tabular}{|c|c|c|c|}
\hline Big 4 & 29.25 & & Financial rating measure and evaluate \\
\hline Non Big 4 & 16.55 & 0.016 & audit firm performance of financial \\
\hline
\end{tabular}

Table 2: Descriptive statistics and Mann Whitney U test (2)

Using the net profit and total assets, we calculated the return on assets (ROA). The average ROA for all audit firms is $33 \%$, while the average ROA of the Big Four audit firms is 30\%. The average ROA for non Big Four audit firms is $36 \%$.

Total capital: The average total capital of audit firms is HRK 3.233.300, while the average total capital of the Big Four audit firms is HRK 11.581.500. Using the Mann-Whitney U test, the difference between total capital and the type of audit firm was defined (Table 2, Part 3). As can be seen, the mean rank of total capital in the Big Four audit firms was higher (mean rank equivalent to 29.25). Also, based on a significance of $1.6 \%$, we can conclude that there is a significant difference between total capital and the type of audit firm.

Financial ratio: The financial ratio measures the performance of financial activities of audit firms for the financial year and is calculated using one-time processing of data from annual financial statements (Table 2, Part 4). Possible values are marked from $\mathrm{A}$ to $\mathrm{E}$, where $\mathrm{A}$ is the best and $\mathrm{E}$ the worst class of financial ratings. In the first step, audit firms are classified into one of five groups according to the criteria of assets size, while Group 1 represents audit firms with the lowest and 5 with the highest assets size. After classifying the audit firms into groups according to value of assets, the second step involves classifying based on the value of individual financial indicators. Further classification required using financial indicators (gearing ratio, current ratio, EBITDA coverage of expenses, credit exposure from operations, rate of return on assets and productivity of total assets) with the final financial assessment determined by networking the classification results by individual indicators. As can seen in Table 2, Part 4, most of the audit firms have an $\mathrm{A}$ ratio, i.e. the best class of financial ratio (Poslovna.hr).

\subsection{Analysis of disclosing transparency reports}

The audit firms and the independent auditor that carry out audits of publicinterest companies (whose securities are quoted on the stock exchange in the first quotation or in the public companies quotation; banks and other financial institutions; companies of the special state interest, the registered capital of which exceeds 300 mil HRK, in accordance with the decision of the Government of the Republic of Croatia on the listing of companies of the special state interest) within three months of the end of each business year have obligation to publish annual transparency report on their websites or on websites of the Croatian Audit Chamber (Croatian Audit Act, 2012, article 27). 
The transparency report elements are as follows (Croatian Audit Act, 2012, article 17a): (1) a description of the organizational structure and ownership structure of the audit firm and the independent auditor; (2) to which network the audit firm belongs, a description of the network and the legal and structural arrangements in the network; (3) a description of the governance structure of the audit firm and the independent auditor; (4) a description of the internal quality control system of the audit firm or the independent auditor and a statement by the administrative or management body on the effectiveness of its functioning; (5) an indication of when the last quality assurance review took place; (6) a list of public-interest entities for which audits have been carried out during the preceding financial; (7) a statement concerning the audit firm's and the independent auditor's independence practices which also confirms that an internal review of independence compliance has been conducted; (8) a statement on the policy followed by the audit firm and the independent auditor concerning the continuing education of certified auditors; (9) overall financial information and data showing the importance of the audit firm and the independent auditor, such as the total turnover divided into fees from the statutory audit of annual and consolidated accounts, and fees charged for other assurance services, tax advisory services and other nonaudit services; (10) information concerning the basis for remuneration of certified auditors who sign audit reports on audits of public-interest entities. The transparency report is an attempt brings the audit profession closer to the public, especially public-interest companies. According to the Croatian Audit Act, audit firms that audited listed companies are required to publish transparency reports containing all the important transparency report elements [2].

The transparency report $\left(\mathrm{TR}_{\mathrm{INDEX}}\right)$ measured the existence of a transparency report element. There are 10 mandatory elements, meaning that the $\mathrm{TR}_{\text {INDEX }}$ comprises a total of 10 elements. The transparency report index (TR INDEX) is calculated as ratio of the number of existing elements in the transparency report ( $\Sigma$ TR) and the maximum number of transparency report elements (Max TR). If a transparency report element exists, the value is 1 and if an element is not included in the transparency report, the value is 0 . Each item has the same weight [4].

\begin{tabular}{|l|c|c|}
\hline \multicolumn{1}{|c|}{ Element of transparency report } & $\mathrm{n}$ & $\%$ \\
\hline $\begin{array}{l}\text { 1. a description of the organizational structure and ownership } \\
\text { structure of the audit firm and the independent auditor }\end{array}$ & 21 & $60 \%$ \\
\hline $\begin{array}{l}\text { 2. to which network the audit firm belongs, a description of the } \\
\text { network and the legal and structural arrangements in the } \\
\text { network }\end{array}$ & 35 & $100 \%$ \\
\hline
\end{tabular}




\begin{tabular}{|l|l|l|}
\hline $\begin{array}{l}\text { 3. a description of the governance structure of the audit firm and } \\
\text { the independent auditor }\end{array}$ & 28 & $80 \%$ \\
\hline $\begin{array}{l}\text { 4. a description of the internal quality control system of the audit } \\
\text { firm or the independent auditor and a statement by the } \\
\text { administrative or management body on the effectiveness of its } \\
\text { functioning }\end{array}$ & 35 & $100 \%$ \\
\hline $\begin{array}{l}\text { 5. an indication of when the last quality assurance review took } \\
\text { place }\end{array}$ & 29 & $83 \%$ \\
\hline $\begin{array}{l}\text { 6. a list of public-interest entities for which audits have been } \\
\text { carried out during the preceding financial year }\end{array}$ & 35 & $100 \%$ \\
\hline $\begin{array}{l}\text { 7. a statement concerning the audit firm's and the independent } \\
\text { auditor's independence practices which also confirms that an } \\
\text { internal review of independence compliance has been conducted }\end{array}$ & 34 & $97 \%$ \\
\hline $\begin{array}{l}\text { 8. a statement on the policy followed by the audit firm and the } \\
\text { independent auditor concerning the continuing education of } \\
\text { certified auditors }\end{array}$ & 31 & $89 \%$ \\
\hline $\begin{array}{l}\text { 9. overall financial information and data showing the importance } \\
\text { of the audit firm and the independent auditor, such as the total } \\
\text { turnover divided into fees from the statutory audit of annual and } \\
\text { consolidated accounts, and fees charged for other assurance } \\
\text { services, tax advisory services and other non-audit services }\end{array}$ & 35 & $100 \%$ \\
\hline $\begin{array}{l}\text { 10. information concerning the basis for remuneration of certified } \\
\text { auditors who sign audit reports on audits of public-interest } \\
\text { entities }\end{array}$ & 35 & $100 \%$ \\
\hline
\end{tabular}

Table 3: Number of audit firms that have a TR element

1. In all, $60 \%$ of audit firms provided a description of the organizational structure and ownership structure. All audit firms provided a description of the organizational structure, but we did not find information about the audit firm ownership for 14 audit firms.

Comment: We recommend that audit firms need to provide information about owner structure and show the number of each auditor shares directly in TR (without checking information about ownership structure in Croatian Audit Chamber which is current practice).

2. All audit firms provided information as to which network the audit firm belongs, a description of the network and the legal and structural arrangements in the network

Comment: While all audit firms provided information as to which network they belong, there is scant legal and structural data of the network in the transparency report. We recommend that audit firms belong to a network provide the minimum following information: since when has the audit firm being a member of the 
network, the reason for joining the network, the number of audit firms included in the network and the main goals of the network.

3. In all, $80 \%$ of audit firms provided a description of the governance structure of the audit firm and the independent auditor.

Comment: The level of disclosure the audit firms on governance structure is inadequate. We recommend that audit firms provide information on governance structure and specify the names of Management Board. Also, to highlight the importance of the transparency report, requesting governance structure information only from the Croatian Audit Chamber is insufficient.

4. All audit firms provided information on the description of their internal quality control system in their audit firm or the independent auditor, as well as a statement by the administrative or management body on the effectiveness of its functioning.

Comment: We recommend that audit firms provide more information on the following: ethical standards (integrity, objectivity and independency), responsibility for the internal control system, acceptance and continuation of relations with the client, human resource management (recruitment, professional development and advancement) and performing the actual auditing (methodology, technology and audit team design).

5. In all, $83 \%$ of audits firms provided information during the last quality assurance review.

Comment: It is important to show a date when the last quality assurance review took place. For voluntary disclosure, we also recommended that audit firms provide more detailed information on external monitoring results as implemented by the Croatian Audit Chamber.

6. All audit firms show a list of public-interest entities for which audits have been carried out during the preceding financial year.

Comment: There are no additional comments for this element of the transparency report.

7. In all, $97 \%$ of audit firms provide a statement concerning the audit firm's and the independent auditor's independence practices, confirming that an internal review of independence compliance has been conducted.

Comment: Most of the independence statements are unclear with respect to independent politics and verification of independence. We recommended audit firms develop a program and system for monitoring independence. In this part, it is unclear how independence is measured (financial relations, working and 
business relations, the provision of non-audit services, auditors' rotation and audit fees).

8. In all, $89 \%$ of audit firms provided a statement on the policy of ongoing education for certified auditors by the audit firm and the independent auditor.

Comment: We recommended audit firms provide information as to where auditors received ongoing education (requires at least 20 hours of ongoing professional education each year and at least 120 hours over a period of three years).

9. All audit firms provided financial information and data indicating the importance of the audit firm and the independent auditor, where such information related to total turnover divided into fees from the statutory audit of annual and consolidated accounts, and fees charged for other assurance services, tax advisory services and other non-audit services.

Comment: We recommended that audit firms improve the level of information disclosed in for this element of the transparency report, especially in providing other financial (audit firm assets, liabilities, capital, costs, analysis of financial statements using financial indicators) and non-financial (narrative) information.

10. All audit firms provided information concerning the basis for remuneration of certified auditors who sign audit reports for the auditing of public-interest entities.

Comment: We recommended that audit firms improve the level of information disclosed in this element of the transparency report. Audit firms only pointed out that auditors are awarded a monthly salary. We also recommend that audit firms indicate average monthly salary for auditors.

In addition, the research also delved into how many elements persist in every audit firm's transparency report. After analyzing the transparency, the results indicate that from total of 35 audit firms covered by this analysis, only 11 audit firms are transparent, i.e. their reports have all TR elements (Table 4). 


\begin{tabular}{|l|c|c|}
\hline \multicolumn{1}{|c|}{ The audit firms according to number of TR elements } & $\mathrm{n}$ & $\%$ \\
\hline 8 elements & 8 & 22.9 \\
\hline 9 elements & 16 & 45.7 \\
\hline 10 elements & 11 & 31.4 \\
\hline Total & 35 & 100.0 \\
\hline \multicolumn{1}{|c|}{ Transparent and non-transparent audit firms } & $\mathrm{n}$ & $\%$ \\
\hline Non-transparent & 24 & 68.6 \\
\hline Transparent & 11 & 31.4 \\
\hline Total & 35 & 100.0 \\
\hline
\end{tabular}

Table 4: Transparent and non-transparent audit firms

\subsection{Analysis of transparency report delay}

The transparency report delay ( $\mathrm{TR}_{\mathrm{DELAY}}$ ) is measured as a function of the number of days from the financial year-end to the date of publishing the transparency report. The following model was developed (Equation 1) to identify a relationship between the transparency report delay $\left(\mathrm{TR}_{\mathrm{DELAY}}\right)$ and selected independent variables:

$$
T R_{D E L A Y}=\beta_{0}+\beta_{1} C A+\beta_{2} A U D+\beta_{3} R O A+\beta_{4} T R_{I N D E X}
$$

The relevant dependent and independent variables in the model are shown in Table 5 .

Our model is estimated using multivariate regression analysis to ascertain the influence on the transparency report delay ( $\left.T R_{\text {DELAY }}\right)$. Variables in the multivariate regression utilize the stepwise method. Accordance to the stepwise method, the first variable that enters the model is that with the highest correlation coefficient for the transparency report delay (TR DELAY $)$. The number of certified auditors in 2015 (CA) is the first variable for our first model (Model 1). The second variable is chosen with the highest coefficient of partial correlation for the transparency report delay $\left(\mathrm{TR}_{\mathrm{DELAY}}\right)$. The transparency report index $\left(\mathrm{TR}_{\mathrm{INDEX}}\right)$ is the second variable included in our final model (Model 2).

\begin{tabular}{|l|c|c|}
\hline Variable names & Symbol & Operational measures \\
\hline $\begin{array}{l}\text { Transparency } \\
\text { report delay }\end{array}$ & TR $_{\text {DELAY }}$ & $\begin{array}{c}\text { number of days from the financial year-end to } \\
\text { the date of publishing the TR }(\log )\end{array}$ \\
\hline $\begin{array}{l}\text { Number of } \\
\text { certified auditors }\end{array}$ & CA & number of certified auditors in 2015 \\
\hline $\begin{array}{l}\text { Number of audits } \\
\text { per year }\end{array}$ & AUD & number of audit procedures in 2015 \\
\hline
\end{tabular}




\begin{tabular}{|l|c|c|}
\hline $\begin{array}{l}\text { Profitability } \\
\text { (return on assets) }\end{array}$ & ROA & net income/total assets \\
\hline $\begin{array}{l}\text { Transparency } \\
\text { report index }\end{array}$ & TR $_{\text {INDEx }}$ & $\begin{array}{c}\text { number of elements present in the } \\
\text { transparency report / maximum number of } \\
\text { transparency report elements }\end{array}$ \\
\hline
\end{tabular}

Table 5: Summary of operationalization of variables

Also, based on the stepwise method, variables that have the lowest coefficient of partial correlation with the transparency report delay ( $\left.T R_{\text {DELAY }}\right)$ are excluded from the model. They are the following variables: number of audits per year (AUD) and profitability-return on assets (ROA). The estimated results using multivariate regression are shown in Table 6 and Equation 2.

In addition, the calculated multicollinearity test suggests that collinearity is not a serious issue (i.e. variance inflation factors are less than five). The results show that the number of certified auditors in 2015 (CA) and transparency report index (TR INDEX $_{\text {) }}$ are statistically significant in explaining the transparency report delay $\left(\mathrm{TR}_{\text {DELAY }}\right)$. The transparency report delay (TR $\left.\mathrm{TRELAY}_{\mathrm{DE}}\right)$ is inversely related to the transparency report index ( $\left.\mathrm{TR}_{\text {INDEX }}\right)$ and the number of certified auditors in 2015 $(\mathrm{CA})$.

\begin{tabular}{|c|c|c|c|c|c|c|}
\hline \multirow{2}{*}{ Model } & \multicolumn{2}{|c|}{$\begin{array}{c}\text { Unstandardized } \\
\text { Coefficients }\end{array}$} & \multirow{2}{*}{ Sig. } & \multicolumn{2}{|c|}{ Collinearity Statistics } \\
\cline { 3 - 4 } \cline { 6 - 7 } & B & Std. Error & & Tolerance & VIF \\
\hline \multirow{2}{*}{1} & Constant & 4.689 & .305 & .000 & & \\
\cline { 2 - 7 } & No of CA & -.114 & .040 & .007 & 1.000 & 1.000 \\
\hline \multirow{2}{*}{2} & Constant & 9.917 & 2.450 & .000 & & \\
\cline { 2 - 7 } & No of CA & -.127 & .038 & $.002^{\mathrm{a}}$ & .975 & 1.025 \\
\cline { 2 - 7 } & TR $_{\text {INDEX }}$ & -.569 & .265 & $.040^{\mathrm{b}}$ & .975 & 1.025 \\
\hline
\end{tabular}

* Dependent variable: Transparency report delay.

** Excluded variables (Stepwise): Number of audits, ROA.

${ }^{\text {a }}$ significant at $1 \%$; ${ }^{\text {b }}$ significant at $5 \%$.

Table 6: Estimated results by multiple regression

$$
T R_{\text {DELAY }}=9.917-0.127 C A-0.569 T R_{\text {INDEX }}
$$

This finding highlights that the number of days from the financial year-end and date of publishing the transparency report (TR $\left.\mathrm{TRELAY}_{\mathrm{S}}\right)$ in audit firms is less for audit firms that had a greater number of certified auditors in 2015 (CA) and a higher transparency report index $\left(\mathrm{TR}_{\mathrm{INDEX}}\right)$, i.e. when audit firms present more elements in the transparency report. 


\section{Conclusion}

Audit firms were involved in the large corporate scandals that shook capital markets at the start of the twentieth century, such as Enron, WorldCom and Parmalat. Corporate scandals have caused regulatory authorities to increase the level of audit quality and the level of regulation in audit professions. Consequently, regulatory changes have taken place in the United States, the European Union and even in Croatia. Transparency is the willingness of audit firms to make their information more accessible to the public. Therefore, there is a need for transparency of audit firms to bring their business operations closer to users. Transparency is also the willingness of audit firms to publicly present their structure, policies and operating procedures, and other information in order to reduce asymmetry of information in the audit market.

In order to increase the accountability of audit firms towards the wider community, regulatory bodies in Croatia in 2008 introduced article 17a of the Audit Act with the obligation of publishing TR for audit firms who audit the financial statements of public-interest companies. Through transparency of reporting, audit firms provide insight information on their arrangements, processes and policies, system control that is carried out and financial data. In analyzing firms that audited companies on the Croatian stock exchange, the conclusion is that $45 \%$ of the Croatian listed companies are audited by the Big Four audit firms. The results showed that 35 audit firms audited companies from the ZSE. In exploring the main issue in the paper, i.e., the transparency report, we concluded that only $32 \%$ of audit firms are transparent, when observing through the TR and its elements, and using the TR index. The recommendation is to achieve better transparent and improved reports, and increase the number of TR elements using "voluntary publication" (which has been indicated in the above comments). Also, the number of days from the financial year-end and the date of publishing the transparency report by audit firms is shorter when they have a higher transparency report index, i.e., when audit firms insert more elements into their transparency report. Transparency report disclosure and transparency report delay are very important elements for the quality of audits. These two elements are important for the client's audit firms. The aim of this paper is to show that information presented is necessary for companies and their decision as to deciding on the audit firm that will audit their financial statements. Transparency report disclosure, its timeliness and disclosure to users can contribute significantly to the success of an audit firm. Therefore, the time has come for audit firms to improve the mandatory and especially voluntary elements in their transparency reports. Also, the audit profession should be more committed to this issue. The recommendation is for future research to expand work on the transparency report elements. 


\section{References}

[1] Canadian Public Accountability Board. (2016). Transparency into the AuditAudit Quality Indicators and Transparency Reporting. Available at: http:// www.cpabccrc.ca/Documents/Stakeholders/Audit\%20Committee/CPAB_E xchange_Transparency_Audit.pdf [Accessed 15/12/16].

[2] Croatian Audit Act. (2012). Available at: https://zakon.hr/z/417/Zakon o reviziji [Accessed 15/12/16].

[3] Croatian Audit Chamber. (2016). Available at: https://revizorska-komora.hr [Accessed 15/12/16].

[4] Čular, M. and Maretić, M. (2015). Transparency of audit firms, audit committee effectiveness and internal control existence. 11th International Conference Challenges of Europe: Growth, Competitiveness, Conference Proceedings, 1, $1-15$.

[5] Deumes, R., Schelleman, C., Van der Bauwhede, H. and Vanstraelen, A. (2012). Audit firm governance: do transparency reports reveal audit quality. Auditing: A Journal of Practice \& Theory, 31(4), 193-214.

[6] Ehlinger, A. (2007). Determinants of the extent of disclosure in transparency reports according to Article 40 of the 8th Company Law Directive: First Evidence from Austria, Germany and the Netherlands. The Maastricht Accounting, Auditing and Information Management Research Center, 46-72.

[7] Fu, Y., Carson, E. and Simnett, R. (2015). Transparency report disclosure by Australian audit firms and opportunities for research. Managerial Auditing Journal, 30(8/9), 870-910.

[8] IOSCO. (2015). Transparency of Firms that Audit Public Companies. Available at: https://www.iosco.org/library/pubdocs/pdf/IOSCOPD511.pdf [Accessed 15/12/16].

[9] King, R. (2016). Transparency Reporting in the global limelight. Available at: https://www. charteredaccountants.com.au [Accessed 15/12/16].

[10] Messier, W. F. (2000). Revizija (Auditing). Faber \& Zgombić Plus, Zagreb, Croatia.

[11] Pivac, S. and Čular, M. (2012). Quality index creating and analysis of the transparency of audit firms - case study in Croatia. Croatian Operational Research Review 3(1), 224- 235.

[12] Poslovna.hr (2016). Available at: http://www.poslovna.hr [Accessed 15/12/ 16].

[13] Pott, C., Mock, T. and Watrin, C. (2008). The effect of a transparency report on auditor independence: practitioners' self-assessment. Review of Managerial Science, Springer, 2, 111-127.

[14] Financial Agency (FINA) (2016). Available at: https://rgfi.fina.hr [Accessed $15 / 12 / 16]$. 
[15] Regulation (EU) No 537/2014. (2014). Available at: http://eur-lex.europa.eu /legal-content/EN/TXT/HTML/?uri=CELEX:32014R0537\&from=HR [Accessed 15/12/16].

[16] Zagreb Stock Exchange. (2016). Available at: http://zse.hr [Accessed 15/12/ 16]. 